\title{
DEVELOPMENT OF CONTEXTUAL-BASED STUDENT WORKSHEET ON THE THEME OF ENVIRONMENT OUR BEST FRIEND'S GRADE FIFTH ELEMENTARY SCHOOL OF SUKADANA
}

\author{
Rika Triwinda ${ }^{1}$, Satinem ${ }^{2}$, Tio Gusti Satria ${ }^{3}$ \\ 1,2,3 STKIP-PGRI Lubuklinggau \\ Rikatriwinda99@gmail.com
}

DOI: https://doi.org/10.21107/Widyagogik/v8i2. 8993

Received November 08, 2020; Revised December 08, 2020; Accepted January 21, 2021

\section{Abstract}

This development research aims to develop a Contextual-Based Student Worksheet On The Theme of Environment Our Best Friend's Grade Fifth Elementary School Of Sukadana. The type of research is Research of Development with the Dick \& Carey model. The results showed that the media validation was classified as good with a percentage of $76,85 \%$. Linguistic validation results are categorized as good with a percentage $71,43 \%$. The results of the material validation category are very good with a percentage of $91,25 \%$. Overall the result of the analisys and calculation of questionnaire scores from the expert team, Contextual-Based Student Worksheet are in the good category with a percentage $79,84 \%$. While the result of one to one are classified as good with a percentage of $73,48 \%$. Small group trials are classified as very good a percentage of $86,75 \%$, meaning that is Contextual-Based Student Worksheet On The Theme Of Environment Our Best Friend's grade Fifth of Elementary School Of Sukadana valid and practical to use.

Keywords : Development, Student Worksheet, Contextual. 
40 Development of Contextual-Based Student Worksheet on The Theme of Environment Our Best

Friend's Grade Fifth Elementary School of Sukadana

Rika Triwinda, Satinem , Tio Gusti Satria

\section{Introduction}

Student Worksheets are sheets containing material to solve certain problems. According to Prastowo (2011: 204) Student Worksheets is a printed teaching material in the form of sheets of paper containing material, summaries and instructions for implementing learning tasks that must be done by students, which refers to the basic competencies that must be achieved. Planting concepts in learning activities is expected to be able to provide meaning to students. To support the planting of concepts that provide meaning for students, it is supported by a contextual learning process. Rusman (2010: 187) argues that contextual learning is an attempt to make students active in pumping their own abilities without losing in terms of benefits, because students try to learn concepts as well as apply and relate them to the real world. In contextual learning, the learning material will be linked to the environment where students live, so that it will make it easier for students to understand the learning material provided.

Observations and interviews were carried out on January 10, 2020 in various ways, one of which was related to the application of the curriculum used in the learning process. At this time, the curriculum applied at Elementary School Of Sukadana is the 2013 curriculum. The 2013 curriculum uses a thematic approach. According to Rusman (2010: 258), one of the characteristics of thematic learning is student centered. So that in the learning process it is hoped that students will be more active in finding and finding themselves, while the teacher acts as a facilitator. By seeking and discovering themselves, students will find meaning in learning. However, based on observations, it is known that the learning process is still teacher-centered. Teachers are more dominant in providing learning material.

It appears that there is a gap between the expected state and the real situation that happened. The fifth grade teacher at Elementary School Of Sukadana also said that he had difficulty helping students achieve their learning goals. This is because the material in the 2013 curriculum textbook is short. So that teachers also need other references to support learning. In addition to the various problems above, the next problem is related to the attractiveness of students in learning. Learning resources should have an attractive appearance so that students have a curiosity to learn the material to be taught. The solution, researchers will design learning resources in the form of worksheets developed through theme books and guided by the syllabus. According to Ahmadi (2014: 171) Student work sheets are sheets containing tasks that must be done by students. Student worksheets contains several components. The Ministry of National Education (2008: 25-26) states that there are several components contained in the student worksheets which must contain the title, the KD to be achieved, the completion time, the equipment or materials needed to complete the task, brief information, work steps, tasks to be done, and reports to be done.

Student Worksheets are printed teaching materials in the form of sheets containing questions that are equipped with a summary of the material and title, basic 
competencies to be achieved, completion time, equipment / materials needed and instructions for implementing assignments that will be done by students.

According to Prastowo (2015: 205) student worksheets has four functions, namely:

1) As a teaching material that can minimize the role of educators but further activate the role of students,

2) As teaching materials that make it easier for students to understand the material,

3) As a concise and task-rich teaching material for practicing, as well

4) Facilitate the implementation of teaching to students.

This student worksheets was developed by fulfilling the requirements of a good student worksheets. According to Darmojo and Kaligis in Yunus and Alam (2015: 177) a good student worksheets must meet didactic requirements, construction requirements, and technical requirements. Furthermore, the worksheets that will be made by researchers are contextual-based worksheets. Where the learning material will be associated with real events in the student environment. Lamapaha (2017: 59) argues that contextual learning is one type of learning that is relevant to brain work patterns in general. Contextual learning will stimulate the brain to compose work patterns which will then be able to manifest meaning. Contextual-based student worksheets are printed teaching materials in the form of question sheets that have been developed through thematic books with the material presented in context. So far, the material contained in student books is related to events that have never been experienced by students, this is what causes a lack of student attractiveness in learning, so that students do not understand learning material. It is hoped that the efforts made by researchers by completing the material through student worksheets can be an attractive learning resource for students so that they can support the success of learning for fifth grade students at Elementary School Of Sukadana.

Student worksheets that will be used as a support in the learning process will be adjusted to what the fifth grade students and teachers want at Elementary School of Sukadana. The grade fifth teacher said that the desired worksheets were simple but could support student success in the learning process. Meanwhile, the worksheets that students want are interesting worksheets, such as in color and accompanied by lots of pictures. The worksheets to be made will be adjusted to the wishes of teachers and students in grade Elementary School Of Sukadana. So, the worksheets that will be made by researchers are contextual-based worksheets with designs that are tailored to the needs of teachers and students. Based on these gaps, researchers are interested in conducting development research entitled "Development of Contextual-Based Student Worksheet On The Theme Of Environment Our Best Friend's Grade Fifth of Elementary School Of Sukadana". 
42 Development of Contextual-Based Student Worksheet on The Theme of Environment Our Best Friend's Grade Fifth Elementary School of Sukadana

Rika Triwinda, Satinem , Tio Gusti Satria

\section{Method}

This study aims to develop contextual-based student worksheets. The approach used in this study is a contextual approach using the Dick \& Carey model development research method. In this study, the subjects studied were 16 students of grade fifth at Elementary School Of Sukadana, totaling 16 students on the theme of 8 Our friends' environment, namely the even semester of the 2019/2020 school year.

Data collection was obtained through the use of a questionnaire where respondents gave a check mark $(\mathrm{V})$ according to their answer scores in the table provided. The questionnaire uses a Likert scale, the answers to each question are: very good, good, sufficient, and less. The data analysis used in this study used a scoring technique by calculating the total score on the questionnaire given and described using a Likert scale in the form of a checklist. The steps that will be taken are:

a. Provide a score for each question item.

b. Add up the scores

c. Changing the score data (quantitative) into qualitative.

According to Partino (2009: 21) To change the quantitative score to qualitative there are several steps, namely:

1) Calculate the score range with the formula:

Note:

$$
\mathrm{R}=\mathrm{Sb}-\mathrm{Sk}
$$

$\mathrm{R}=$ Range

$\mathrm{Sb}=$ greatest score

$\mathrm{Sk}=$ smallest score

2) Determine the number of categories $(T)$

3) Calculate the length of the interval for each category, using the formula:

Note:

$\mathrm{P}=$ Length of interval

$$
\mathrm{p}=\frac{1}{T} \mathrm{R}
$$

$\mathrm{T}=$ Category

$\mathrm{R}=$ Range

4) Define category boundaries

5) Give the name or quality of each category.

6) Calculating percent, with the formula:

$$
\mathrm{P}=\frac{n}{N} \times 100 \%
$$

(Rohmad in Ali, 2013: 2)

Note:

$\mathrm{P}=$ Percentage of score $(\%)$

$\mathrm{n}=$ The number of scores obtained

$\mathrm{N}=$ Total maximum score 
The feasibility agreed upon in this study with a minimum value of $\mathrm{C}$ or sufficient.If the results given by the validator, teacher and students obtained a sufficient average score, the development of contextual-based thematic worksheets for Grade Fifth at Elementary School Of Sukadana students at a.

\section{Result and Discussion}

Contextual-based Student Worksheets on the theme of our friend's class $\mathrm{V}$ environment developed by the author have gone through several stages which include validation, evaluation and revision. This stage was passed so that the contextual-based Student Worksheet on the theme of our friend's environment that was tested on fifth grade students at Elementary School Of Sukadana was valid and practical. The following will explain some of these stages:

1. The results of the needs analysis to identify objectives.

a. Needs analysis

At this time, the curriculum applied in Elementary School Of Sukadana is the 2013 curriculum. The 2013 curriculum uses a thematic approach. According to Rusman (2010: 258), one of the characteristics of thematic learning is student centered. The learning process is expected by students to be more active in seeking and discovering themselves while the teacher acts as a facilitator. By seeking and discovering themselves, students will find meaning in learning. However, based on observations, it is known that the learning process is still teacher-centered. It appears that there is a gap between the expected situation and the reality that happened. The fifth grade teacher at Elementary School Of Sukadana said that he had difficulty helping students achieve their learning goals. This is because the material in the 2013 curriculum package book is not explained in detail, some of the subjects briefly explain the core of the material, so teachers also need other references to support learning.

In addition to the various problems above, the next problem is related to the attractiveness of students in learning. The attractiveness of students in learning activities is supported by the learning resources students use. Learning resources should have an attractive appearance so that students have a curiosity to learn the material to be taught. Environmental potential analysis

Furthermore, what is done is to analyze the potential of the environment around Elementary School Of Sukadana. Based on the results of the analysis, it was found that around the environment there were mountains, rice fields and rivers. In addition, there are also economic activities such as trade and agriculture, so that the environment supports the development of a student worksheet based on the contextual theme of our friend's Grade Fifth At Elementary School Of Sukadana. 
44 Development of Contextual-Based Student Worksheet on The Theme of Environment Our Best Friend's Grade Fifth Elementary School of Sukadana

Rika Triwinda, Satinem , Tio Gusti Satria

b. Analysis of curriculum and materials

The curriculum that has been applied in the learning process is the 2013 curriculum the learning approach used is thematic. The learning material is in the even semester on the theme of 8 of our friend's environment which is contained in the 2013 curriculum on core competencies and basic competencies, where the basic competencies contains 5 learning content, namely Indonesian, Science, Social Sciences, PPKn, and SBdP. Each learning content contained in the basic competencies, student learning outcomes must reach the predetermined KKM score of 70 .

c. Student analysis

Grade fifth students of Elementary School Of Sukadana like the learning process that is direct and concrete. Students also want Student Worksheets that are colorful and accompanied by lots of pictures.

d. Identify goals

The population in this study was grade fifth of Elementary School Of Sukadana with a total of 16 students. The discrepancy in this study shows that before using a contextual-based student worksheet on the theme of our friend's environment, the students' scores had not reached the KKM. This is influenced by the textbooks used by students in the learning process which are the main source not equipped with supporting books. The material presented in the book is not yet in context with the environment around the students, so students need supporting books that are contextual to make it easier to understand the material provided in the learning process. Therefore, the authors are interested in providing solutions to this problem by developing a supporting book in the form of contextual-based Student Worksheets.

2. Learning Analysis

According to Darmojo and Kaligis in Yunus (2015: 177), a good student worksheet must meet the requirements including deactivation, construction and technical requirements. Based on the results of the analysis, the contextual-based student worksheet has met the three requirements, but on the technical requirements, the student worksheet has not met the third point, which is related to the appearance of the student worksheet which is considered not attractive.

3. Learner analysis and context.

Class V students are enthusiastic and curious. So that the authors stimulate the character of these students by giving students the opportunity to work independently and work in groups or small group discussions. Individual or independent activities cultivate the confidence that students have with their abilities. Meanwhile, group activities or discussions make students more active in working together.

4. Write a performance goal. 
The objectives are formulated by fulfilling the $A B C D$ (audience, behavior, condition and degree) requirements. The learning objectives include; a) students can identify various forms of floor patterns correctly and confidently, b) students can explain the meaning of floor patterns correctly and confidently, c) students can demonstrate floor patterns of regional creation dance movements correctly and responsibly, d) students can explain about the availability of clean water appropriately and responsibly, e) students can make poster work about the impact of the water cycle on life correctly and confidently, f) students can identify the types of businesses that

managed themselves properly and responsibly, g) students can identify the diversity of types of businesses in the surrounding environment correctly and responsibly, h) students can present the results of an analysis of the economic role of each type of business correctly and responsibly, i) students can identify uniqueness customs in the socio-cultural diversity of Indonesian society correctly and responsibly and j) students can identify events and incidents in reading correctly and responsibly.

1. Develop an assessment instrument.

The assessment instrument in this study is in the form of questions contained in the product that has been developed by the author, namely the Student Worksheet based on the contextual theme of our friend's environment. Acquisition of student scores with a maximum achievement score of 100.

2. Development of learning strategies.

The development of learning strategies is needed to help achieve the goals of learning through developing the products used. The learning strategy used by the author is a contextual-based approach.

3. Development and selection of learning materials.

The product developed by the author is a supporting book in the learning process, namely in the form of Student Worksheets based on the contextual theme of our friend's environment.

4. Conduct formative evaluation.

a. Expert validation

1) Media Expert

Based on the validation of media experts, contextual-based Student Worksheets are categorized as Good. The results of the analysis can be seen in the table below: 
Table 1. Percentage of media expert ratings

\begin{tabular}{|c|c|c|}
\hline Rang & Percentage & Category \\
\hline $87.78-108$ & $81.28 \%-100 \%$ & Very Good \\
\hline $67.52-87.77$ & $62.52 \%-81.27 \%$ & Good \\
\hline $47.26-67.51$ & $43.76 \%-62.50 \%$ & Enough \\
\hline $27-47.25$ & $25 \%-43,75 \%$ & Less \\
\hline
\end{tabular}

Based on these results, it can be seen that the appropriateness of the Student Worksheet media based on the contextual theme of our friends' environment is categorized as "Good" with a percentage of $76.85 \%$.

1) Language Expert

The results of the language validation from the validator can be seen in the following calculation results:

Table 2. Percentage of linguist assessment

Table 2. Percentage of linguist assessment

\begin{tabular}{|c|c|c|}
\hline Rang & Percentage & Category \\
\hline $45.8-56$ & $81.78 \%-100 \%$ & Very Good \\
\hline $35.2-45.7$ & $62.86 \%-81.61 \%$ & Good \\
\hline $24.6-35.1$ & $43.9 \% 3-62.68 \%$ & Enough \\
\hline $14-24.5$ & $25 \%-43.75 \%$ & Less \\
\hline
\end{tabular}

Based on the results of the student worksheet language expert based on the contextual theme of our friend's environment, it is categorized as "Good" with a percentage of $71.43 \%$.

1) Material Expert

The following is the calculation of the results of the material expert validation:

Table 3. Percentage of material expert judgment

\begin{tabular}{|c|c|c|}
\hline Rang & Percentage & Category \\
\hline $68-83$ & $85 \%-100 \%$ & Very Good \\
\hline $52-67$ & $65 \%-83.75 \%$ & Good \\
\hline $36-51$ & $45 \%-63.75 \%$ & Enough \\
\hline $20-35$ & $25 \%-43.75 \%$ & Less \\
\hline
\end{tabular}

The results of the material experts on the contextual-based Student Worksheet on the theme of our friends' environment are categorized as "Very Good". The percentage of material experts is $91.25 \%$.

Based on the assessment on the student worksheet based on the contextual theme of the environment of our friends grade fifth of Elementary School Of Sukadana obtained through media experts, linguists and material experts, it can be seen as a whole as follows: 
Table 4. Percentage of assessment of all experts

\begin{tabular}{|c|c|c|}
\hline Rang & Percentage & Category \\
\hline $198.28-244$ & $81.26 \%-100 \%$ & Very Good \\
\hline $152.52-198.27$ & $62.51 \%-81.25 \%$ & Good \\
\hline $106.76-152.51$ & $43.75 \%-62.50 \%$ & Enough \\
\hline $61-106.75$ & $25 \%-43.75 \%$ & Less \\
\hline
\end{tabular}

Assessment of all components in the "Very Good" category with a percentage of $80.33 \%$

a. One to One Test

The results of the one to one test on the contextual-based Student Worksheet on the theme of our friend's environment grade fifth of Elementary School Of Sukadana were carried out on four indicators, namely ease, language, interest, and material. Based on the results of the one to one test that was carried out on three students, two people stated that the student worksheet was good enough, while one student stated that there was input. So that through this one to one test, the worksheets must be revised to then carry out small group trials. The percentage of the questionnaire assessment on the one to one test can be seen in the table below:

Table 5. Percentage of student assessments

\begin{tabular}{|c|c|c|}
\hline Rang & Percentage & Category \\
\hline $35.78-44$ & $81.32 \%-100 \%$ & Very Good \\
\hline $27.52-35.77$ & $62.54 \%-81.29 \%$ & Good \\
\hline $19.26-27.51$ & $43.77 \%-62.52 \%$ & Enough \\
\hline $11-19.25$ & $25 \%-43.75 \%$ & Less \\
\hline
\end{tabular}

Skala yang menggambarkan skor minimal, nilai kuartil 1, median, dan nilai kuartil 3 serta skor maksimal adalah sebagai berikut:

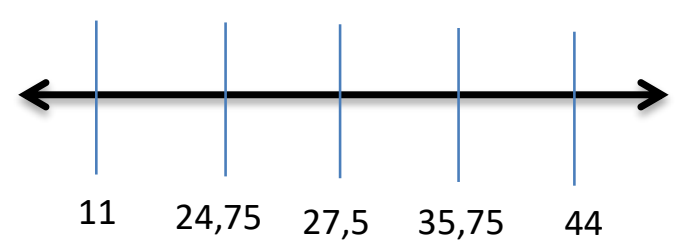

Table 6. Percentage of one to one test

\begin{tabular}{|c|c|c|}
\hline Category & Rang & Percentage \\
\hline Very Good & $35,75-44$ & $81.25 \%-100 \%$ \\
\hline Good & $27,5-35$ & $62.5 \%-79,54 \%$ \\
\hline
\end{tabular}


48 Development of Contextual-Based Student Worksheet on The Theme of Environment Our Best Friend's Grade Fifth Elementary School of Sukadana

Rika Triwinda, Satinem , Tio Gusti Satria

\begin{tabular}{|c|c|c|}
\hline Enough & $24,75-27$ & $56,25 \%-61,36 \%$ \\
\hline Less & $11-24$ & $25 \%-54,55 \%$ \\
\hline
\end{tabular}

Percentage $=\frac{\text { average score }}{\text { maximum score }}=\frac{32,33}{44}=73,48$

Based on the questionnaire assessment obtained through the one to one test on the student worksheet based on the contextual theme of our friend's environment, grade fifth of Elementary School Of Sukadana was categorized as "good" with a percentage of $73.48 \%$.

\section{a. Small Group Evaluation}

The small group evaluation was carried out on May 2, 2020. The small group evaluation was carried out on six grade $\mathrm{V}$ students, by gathering the students into one. The scale that describes the minimum score, the value of the quartile 1 , the median, and the value of the quartile 3 and the maximum score is as follows:

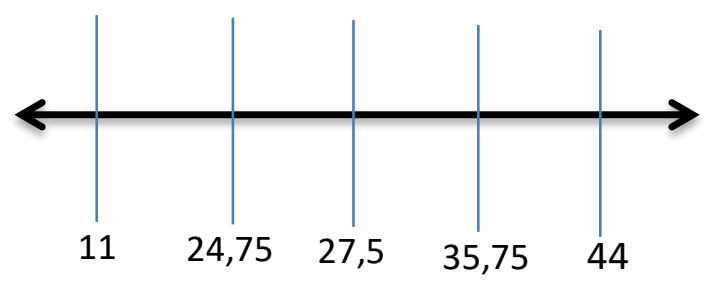

Table 7. Percentage of small groups

\begin{tabular}{|c|c|c|}
\hline Category & Rang & Percentage \\
\hline Very Good & $35,75-44$ & $81.25 \%-100 \%$ \\
\hline Good & $27,5-35$ & $62.5 \%-79,54 \%$ \\
\hline Enough & $24,75-27$ & $56,25 \%-61,36 \%$ \\
\hline Less & $11-24$ & $25 \%-54,55 \%$ \\
\hline
\end{tabular}

Percentage $=\frac{\text { average score }}{\text { maximum score }}=\frac{38,17}{44}=86,75$

The percentage obtained was $86.75 \%$ in the "very good" category. Student Work based on the contextual theme of our friend's grade fifth of Elementary School Of Sukadana is said to be practical.

1. Revision

The revision was carried out in accordance with the previous stages, where there were input that would be used to revise Student Worksheets based on the contextual theme of our friend's environment in grade fifth of Elementary School Of Sukadana before this product would be produced and used for students. 


\section{Discussion}

Researchers conducted a needs analysis starting with observations and interviews conducted with teachers and students in grade fifth. Through these observations and interviews, the researchers found that the curriculum used in grade fifth of Elementary School Of Sukadana was the 2013 curriculum, so the learning process was in the form of a network of themes. The books used in the learning process are teacher books and student books published by the 2017 revised edition of the Ministry of Education and Culture of the Republic of Indonesia. Based on the results of the analysis of the needs of the researcher, the researcher can develop a student worksheet based on the contextual theme of our friend's grade fifth of Elementary School Of Sukadana environment.

The next process, researchers began to design Student Worksheets based on the contextual theme of our friend's environment. This worksheets was built using a contextual approach which contained four components, namely: a) constructivism. This component emphasizes the cognitive aspects that are built in stages (process). Piaget in Satria and Egok (2020: 15) said that cognitive is how children adapt and interpret objects and events around them. b) discovery, c) asking questions and d) learning society. Researchers are also assisted by the main supervisor and assistant mentors to design Student Worksheets. Researchers also received criticism and suggestions by examiners at the proposal seminar as an improvement in designing Student Worksheets.

The cover design of Student Worksheets for students and teachers contains a picture of a hand holding the earth with two color variations. The image was chosen by researchers who interpreted it as the earth and humans living side by side, various advances and damage on earth were derived from humans. Therefore, humans and the earth as the environment live side by side. This image fits the theme of our friend's environment. Furthermore, the authors designed the contents of the Student Worksheet with a Full Collor in order to attract the enthusiasm of students in learning.

The validity of Student Worksheets is carried out to determine the feasibility of Student Worksheets before being tested. Validation stage through three validators. Validators are people who are experts in their fields. The three validations are validation of design, language and materials. Based on the results of the validation carried out through a questionnaire on the Student Worksheet based on the contextual theme of our friend's environment in grade fifth of Elementary School Of Sukadana, media experts scored $76.85 \%$ in the "good" category. Linguists get a score of $71.43 \%$ in the "good" category. Whereas for the material expert the researcher got a score of $91.25 \%$ in the very good category. Through these values, it is known that the contextual-based student worksheet is valid and ready to be tested.

The first trial was carried out on the One to One test. This trial was conducted on three grade $V$ students with different abilities. Through the One to One test, the researcher got an overall score of $73.48 \%$ in the "good" category. Furthermore, the 
50 Development of Contextual-Based Student Worksheet on The Theme of Environment Our Best

Friend's Grade Fifth Elementary School of Sukadana

Rika Triwinda, Satinem , Tio Gusti Satria

researcher revised the product first before conducting the small group test. The small group test got an overall score of $86.75 \%$ with the very good category. Through the One to One test and small group trials, it was found that the student worksheet based on the contextual theme of the classroom environment of Elementary School Of Sukadana was practical to use.

\section{Conclusion}

\section{Conclusion}

In general, contextual-based student worksheets are designed to accommodate a contextual approach to the theme of our friendly environment and are supported by the potential of the environment around Elementary School Of Sukadana . Meanwhile, in particular it can be concluded that:

1. Contextual-based Student Worksheets are used as support in learning activities to make it easier for students to understand material on the theme of our friend's environment. Worksheets are designed with attractive and full color images so as to generate enthusiasm and attractiveness of students in participating in learning activities.

2. Contextual-based Student Worksheets are designed using two types of letters, namely Book Antiqua and Jokerman. Student Worksheets is printed to resemble a book in general, using A4 paper weighing $800 \mathrm{gr}$. Worksheets are accompanied by pictures that match the material on our friend's environmental theme. Selection of colors with good resolution, bright, and full color motivates students to be enthusiastic in learning activities.

3. The validity of contextual-based Student Worksheets is shown through the results of expert validation including media experts, linguists, and material experts. Based on

the validation results, it is known that contextual-based student worksheets are categorized as good with a percentage of $79.84 \%$, so that the contextual-based student worksheets based on the contextual theme of our friends' environment is categorized as valid.

4. The practicality of Student Worksheets is measured through the results of a questionnaire obtained with two stages of testing which include individual trials (one to one) and small group trials. Individual trials or one to one involving 3 randomly selected students with different abilities were categorized good with a percentage of $73.48 \%$, while small group trials involving 6 students were categorized as very good with a percentage of $86.75 \%$. Based on the results of the trial, it is known that student responses are categorized as good which means that the student worksheet is contextually based on the theme of our friend's environment is practical or easy to use. 


\section{Suggestion}

Based on the above research results, the authors suggest:

1. For students, the results of this study can be used as a reference for students to carry out development research on contextual-based student worksheets.

2. For Higher Education (PT), the results of this study can be used as a contribution of suggestions in improving the quality of education.

3. For other writers who want to develop Student Worksheets, it is necessary to further identify the Student Worksheets based on the contextual theme of our grade fifth.

\section{References}

Ahmadi, Khoiru L. dan Sofan Amri. 2014. Pengembangan dan Model Pembelajaran Tematik Integratif. PT Prestasi Pustakaraya: Jakarta-Indonesia.

Depdiknas. 2008. Panduan Pengembangan Bahan Ajar. Jakarta: Departemen Pendidikan Nasional

Lamapaha. Y. F. 2017. Pengembangan Lembar Kerja Siswa Berbasis Kontekstual Beorientasi Penalaran Saintifik. Jurnal Pendidikan Matematika dan Sains. 5 (1), 58-68

Partino., \& M. Idrus. 2009. Statistik Deskriptif. Yogyakarta : Safiria Insania Press

Prastowo, Andi. 2011. Panduan Kreatif Membuat Bahan Ajar Inovatif. DIVA Press: Baguntapan Jogyakarta.

Prastowo, Andi. 2019.Analisis Pembelajaran Tematik Terpadu. KENCANA: Jakarta.

Rohmad, A., Suhandini. P., \& Sriyanto. 2013. Pengembangan Lembar Kerja Siswa (LKS) Berbasis Eksplorasi, Elaborasi Dan Konfirmasi (EEK) Serta Kebencanaan Sebagai Bahan Ajar Mata Pelajaran Geografi SMA/MA Di Kabupaten Rembang. Edu Geografi: Universitas Negeri Semarang, Indonesia. 1 (2), 1-5

Rusman. 2010. Model-model Pembelajaran. PT Raja Gravindo Persada: Jakarta.

Satri, G. T. \& Egok, A.S. (2020). Pengembangan Etnosains Multimedia Learning Untuk Meningkatkan Kognitif Skill Siswa SD Di Kota Lubuklinggau. Jurnal Basicedu: Research And Learning In Elementary School. 4 (1), 13-12

Vanny, A.H., \& Yunus, H. Perencanaan pembelajaran berbasis kurikulum 2013. Yogyakarta : CV Budi Utama

Yunus, H. \& Alam, H. V. (2013). Perencanaan pembelajaran berbasis kurikulum. Yogyakarta : CV Budi Utama 